Д. Ш. Харанутова, А. И. Малаткина. К происхождению некоторых заимствований в региональном языке (на примере регионализма пинка/пимка)

УДК 811.161.1: 39

DOI: 10.18101/2305-459X-2020-2-39-45

\title{
К ПРОИСХОЖДЕНИЮ НЕКОТОРЫХ ЗАИМСТВОВАНИЙ В РЕГИОНАЛЬНОМ ЯЗЫКЕ (на примере регионализма пинка/пимка)
}

\author{
(c) Харанутова Дарима Шагдуровна \\ доктор филологических наук, \\ Бурятский государственный университет имени Доржи Банзарова \\ Россия, 670000, г. Улан-Удэ, ул. Ранжурова, 6 \\ dkharanutova@mail.ru \\ (C) Малаткина Анастасия Ильинична \\ обучающийся, \\ Бурятский государственный университет имени Доржи Банзарова \\ Россия, 670000, г. Улан-Удэ, ул. Ранжурова, 6 \\ annastas2407@gmail.com
}

\begin{abstract}
Аннотация. Работа посвящена одной из проблем региональной лингвистики - вопросу происхождения регионализмов, который рассматривается на примере слова пинка/пимка. В статье раскрываются понятия региолект и регионализм. Даются разные версии возникновения данного регионализма, одна из которых связана с заимствованием из английского, приводятся результаты опроса, проведенного в ходе исследования. Реконструкция этимологических связей предполагает обращение к толковым и этимологическим словарям. В исследовании отмечается, что Этимологический словарь заимствований под редакцией А. Е. Аникина позволил найти ответы на многие вопросы. В приводимой словарной статье этимология интересуемого слова выявляется в аспекте праславянского языка как источника. Авторы склонны считать, что цепочка праславянский $\rightarrow$ тунгусо-маньчжурский $\rightarrow$ старожильческие говорь $\rightarrow$ региональный язык наиболее точно отражает происхождение слова пинка/пимка. Ключевые слова: региолект; регионализм; заимствования; этимологические словари; толковые словари; словарная статья.
\end{abstract}

\section{Для цитирования:}

Харанутова Д. Ш., Малаткина А. И. К происхождению некоторых заимствований в региональном языке (на примере регионализма пинка/пимка) // Вестник Бурятского государственного университета. Язык. Литература. Культура. 2020. Вып. 2. С. 39-45.

Изучение региональных особенностей языка и речи - достаточно популярное направление современной русистики, к центральным понятиям которого относятся понятия «региолект» и «регионализм» (А. С. Герд, 2001, 2005; В. И. Трубинский, 1991; В. И. Беликов, 2004; Е. М. Оглезнева, 2008, 2013, 2014 и др.).

Традиционно под региолектом понимается «особая форма устной речи, ограниченная определенной территорией своего функционирования〉 [8, с. 22]. На сегодняшний день это понятие расширилось, потому что региолект не является «ни говором с определенной структурой, ни однородной языковой системой, так как известно, что в ней преобладает общенациональная форма языка, измененная под действием местных говоров» [О. Блок, цит. по: 5, с. 30]. Таким обра- 
зом, можно говорить о его синонимии с понятием региональный вариант общенародного языка. Итак, «региолект - это такое языковое образование, которое призвано обслуживать повседневное общение носителей языка в том или ином регионе полиэтнического языкового сообщества независимо от их социального положения, возраста, пола и т. п.» $[13$, с. 15].

Региональные особенности русского языка Байкальского региона географически очерчивается территорией Бурятии, Иркутской области и Забайкальского края [10, с. 5].

Для обозначения региональных лексем из существующего ряда терминов (регионализм, локализм, провинциализм) наиболее точным, на наш взгляд, является термин регионализм.

По мнению Т. А. Кадоло, к регионализмам следует относить «слова, функционирующие на определенной территории, не зафиксированные в толковых словарях литературного языка или получающие в них пометы обл., местн., прост., разд.» [12, с. 22]. Более уточненное определение находим у И. С. Зварыкиной: под понятием «регионализм» понимается «единица языка того или иного региона, которая, в отличие от диалектного слова, используется жителями вне зависимости от различных социальных факторов (пол, возраст, образование и т. п.) преимущественно в устной коммуникации, но также функционирует в текстах художественной литературы, региональных СМИ» [11, с. 214].

Что касается образования регионализмов, безусловно, одним из путей появления регионализмов является заимствование слов. Состав и характер заимствованной лексики русского языка Байкальского региона представляет собой пестротканый ковер, в котором наряду с заимствованиями из языков коренных народов, старожильческих говоров присутствуют и вкрапления из говоров старообрядцев (семейских) и др.

Следует отметить, что в словарном составе русского языка Байкальского региона встречаются регионализмы, происхождение которых установить довольно трудно. Одним из случаев подобного рода, как нам кажется, является судьба регионализма пинка/пимка, употребляющегося в значении «булавка».

Лексему пинка/пимка мы смело можем отнести к регионализмам, так как она функционирует на большей части Байкальского региона и обладает всеми характерными чертами регионализмов: ее функционирование территориально ограничено, слово активно используется в русской разговорной речи региона.

Повсеместность и частотность употребления данной лексемы в нашем регионе выявлены в ходе опроса на знание слова пинка/пимка. Всего в опросе приняли участие 246 человек. Информанты были разделены на три возрастные группы: к первой относятся 48 респондентов старше 50 лет, ко второй - 86 респондентов от 30 до 49 лет включительно, третью группу составили студенты высших учебных заведений г. Улан-Удэ, возрастной состав 18-22 года - 112 человек. При опросе постарались охватить жителей всех районов Республики Бурятия, Иркутской области и Забайкальского края.

Таким образом, в результате статистического анализа данных, полученных при анкетировании, выявилось, что в первой возрастной группе знают и употребляют интересуемое слово 76 процентов из числа респондентов, во второй 
Д. Ш. Харанутова, А. И. Малаткина. К происхождению некоторых заимствований в региональном языке (на примере регионализма пинка/пимка)

группе чуть меньше - 54\%. В третьей возрастной группе всего $32 \%$ ответили утвердительно.

Большая часть из употребляющих слово пинка/пимка - жители Иркутской и Читинской областей или выходцы из этих областей. В Республике Бурятия анкетирование показало, что участники опроса, родившиеся и выросшие в таких районах республики, как Закаменский, Мухоршибирский, Джидинский, не знают его. Двое респондентов утверждали, что оно исконно семейское, так как его употребляют в обиходной речи их бабушки.

При анализе территориального разделения функционирования слова пин$\kappa a /$ илка выявлено, что в Иркутской области его знают только жители деревень Приангарья, живущие вдоль Братского водохранилища, жители северных районов, например города Верхоленска, в Забайкальском крае оно повсеместно употребляется жителими Агинского национального округа. Также в ходе опроса первых двух возрастных групп выяснилось, что потомки переселенцев с запада России, осевшие на севере Иркутской области, никогда не употребляли ранее слово пимка. Зато потомкам коренных сибиряков это слово знакомо с детства, его в речи использовали их бабушки и дедушки.

Второй этап исследования - лексикографический. Для того чтобы ответить на вопросы: откуда все-таки пришло данное слово (в том, что это слово заимствованное, не было никаких сомнений), почему оно «осело» именно в Байкальском регионе, причем тоже избирательно, почему в некоторых местах оно произносится пимка, а в других пинка, мы обратились к словарям.

В процессе исследования возникло несколько версий происхождения слова пинка/пимка.

Первое предположение: лексема пинка/пимка заимствована из английского языка, так как она структурно и семантически точно соответствует английскому pin '1. булавка <...> [3, с. 404]. Анализируемое слово имеет то же звучание и значение, что и английское слово. Логика подсказывает, что если слово пин$\kappa a / n u м к а$ пришло в нашу разговорную речь через заимствование из английского языка, то оно должно относиться к общелитературному языку и встречаться в толковых словарях русского языка.

Данное слово в значении «булавка» не обнаружено ни в словаре С. Н. Ожегова [18], ни в словаре Д. Н. Ушакова [21], ни в словаре В. И. Даля [9]. Таким образом, версия о заимствовании из английского не подкреплена фактом употребления в литературном языке.

Проблематика, связанная с происхождением слов, безусловно, предполагает обращение к этимологическим словарям. В «Этимологическом словаре русского языка» Макса Фасмера находим слово пинка, но оно толкуется как «небольшое транспортное судно»: `впервые пинк, Журнал Петра В.; см. Смирнов, 226. Из нидерл., нж.-нем. pink «рыбачья лодка» или ср.-нж.-нем. pinke; ср. англ. pink - то же (см. Фальк-Торп, 828); ср. Маценауэр, LF 12, 341' [20, с. 263].

По мнению А. Е. Аникина, «словарь Фасмера предлагает высококлассную разработку индоевропейских (в самом широком смысле, включая и генетические отношения и заимствования) связей русской лексики» $[1$, c. 5]. С другой стороны, как отмечает А. Е. Аникин, «есть, однако, целые пласты лексикона, фасмеров- 
ская разработка которых выглядит в той или иной степени недостаточной» [1, с. 5]. По-видимому, интересующая нас лексема попала именно в этот пласт.

Итак, второе предположение: слово пинка/пимка пришло из семейских говоров (диалектное слово). Да, в «Словаре говоров старообрядцев (семейских) Забайкалья» слово пинка уже определяется как «булавка»: «ПИНКА [пинка], -и, ж. Булавка» [17, с. 344], но не более того. Зато в словаре имеется обширная словарная статья по слову булавка: «БУЛАВКА [бла́ўка / була́ўка / була́фка], -и, ж. Брошь» $[17$, с. 58]. По-видимому, более употребительным является слово булавка, в словарной статье приведены многочисленные примеры из материалов, собранных во время диалектологических экспедиций.

Более пространное обьяснение и описание происхождения анализируемого слова находим в словаре А. Е. Аникина, где указывается, что пимка 'булавка' встречается в амурских говорах с ссылкой на Приамурский словарь. Далее, «пимка, пинка `английская булавка' ирк. (Ирк. сл. 2: 131), пинка, пимка ирк., бурят., пимка то же прибайк., чит., урал., пимка 'заколка для волос' (СРНГ 27: 33) [2, с. 448]. Таким образом, А. Е. Аникин указывает, что исследуемая лексема встречается не только в Иркутской и Читинской областях, Бурятии, но и на Амуре и в уральских говорах.

Вторая часть словарной статьи (этимологическая зона), в которой содержится сравнительно-историческая информация, указывает на тунгусо-маньчжурские связи. В словарной статье читаем, что слово пимка «согласно И. Г. Добродомову (ДЛ 1979: 90), неотделимо от "тунгусского лексического материала", т. е. от эвенк. П-Т, Е, Н пинка 'булавка', сюда же нан. пймкэ то же (ТМС 2: 38)» [там же].

Далее А. Е. Аникин стремится уточнить, «связь несомненна, но речь идет о заимств. из рус. в т-маньчж. (не наоборот). Рус. пинка ${ }^{\circ}<$ праславянское *pinъka (дериват с суф. вka от *pinati, далее к *peti 'натягивать, напрягать', ср. рус. запинка и проч., Ан. ИТИТМЯ 1988: 119). [досиб.]» [там же]. Важное уточнение о направлении заимствования прочитывается в употребленном знаке <. Как указывает автор словаря в предисловии, «когда лексическая зона содержит немного материала и отношение между рассматриваемым словом и его этимоном не нуждается в оговорках, знак // может заменяться на знак $<$, указывающий на направление заимствования» [1, с. 12], что и наблюдаем в нашем случае. Таким образом, А. Е. Аникин не сомневается, что сибирская лексема пинка берет начало в праславянском pinъka.

Ответ на вопрос, откуда же появилась в Сибири пинка, кроется в помете «досиб.», которое указывает на «досибирское» происхождение рассматриваемого слова. «Досибирский» - «т. е. занесенный в Сибирь с территорий к западу от нее» [1, с. 11]. Согласно А. Е. Аникину, слово пинка/пимка представляет собой заимствование «из уральских и алтайских языков, которые попали в русские говоры, локализованные к западу от Сибири, и были занесены предками русских сибирских старожилов на восток» [1, с. 10].

Как видим, однозначного ответа на вопрос о происхождении и реконструкции путей-дорог этого слова нет.

Вариант происхождения слова пинка/пимка Байкальского региона как заимствования из английского приемлем лишь отчасти, в формальном плане. На наш 
Д. Ш. Харанутова, А. И. Малаткина. К происхождению некоторых заимствований в региональном языке (на примере регионализма пинка/пимка)

взгляд, второй вариант, определяющий его как заимствование, пришедшее к нам из старожильческих говоров, наиболее точно отражает происхождение слова, как и указание на общеславянский источник. Примерная схема появления регионализма пинка/пимка выглядит так: праславянский $\rightarrow$ тунгусо-маньчжурский (эвенкийский) $\rightarrow$ старожсильческие говоры $\rightarrow$ региональный язык.

Данная схема, безусловно, ждет своего подтверждения. Кстати, результаты опроса можно посчитать одним из аргументов в пользу данной гипотезы, например в Иркутской области как наиболее частотные районы распространения этого слова являются Приангарье, север Иркутской области, а эти места известны как места проживания эвенков. В энциклопедическом этнографо-историческом издании «Буряты» указано, что «еще в начале XIX века вокруг Байкала обитало довольно значительное количество эвенков, которые назывались байкальскими тунгусами. Они занимали таежные места по берегам Лены и Ангары, обитали в Саянах, недалеко от Иркутска и Верхнеудинска, по современному административному делению - в Заиграевском, Хоринском, Еравнинском районах Республики Бурятия и далее в Читинской области. Об этом подробно пишет академик А. Шифнер в предисловии к тунгусской грамматике А. Кастрена» [6, с. 228].

Таким образом, предложенная А. Е. Аникиным реконструкция этимологических связей слова пинка/пимка объясняет, почему оно встречается в говорах Приамурья, уральских говорах и проявляет избирательность по ареалу употребления в Иркутской области, Забайкальском крае и Бурятии.

Итак, для полного описания региолекта, безусловно, необходимо принимать во внимание все факторы, влияющие на его формирование. При этом следует отметить особую роль заимствований в процессе становления регионального варианта русского языка.

Обращение к этимологии слова, реконструкция «дорожной карты» его появления в языке региона позволяют выявить межъязыковые связи, найти причины, движущие механизмы как лингвистического, так и экстралингвистического характера.

\section{Литература}

1. Аникин А. Е. Этимологический словарь заимствований в русских диалектах Сибири. Пробный выпуск. М., Новосибирск: Изд-во СО РАН, 1995. 89 с.

2. Аникин А. Е. Этимологический словарь русских диалектов Сибири: Заимствования из уральских, алтайских и палеоазиатских языков. Новосибирск: Наука, 2000. 768 с.

3. Англо-русский словарь / под ред. О. С. Ахмановой, Е. А. Уилсон. М. Изд. 25-е. М.: Русский язык, 1975. 640 с.

4. Беликов В. И. Сравнение Петербурга с Москвой и другие соображения по социальной лексикографии // Русский язык сегодня: сб. ст. Вып. 3. Проблемы современной лексикографии. М.: ИРЯ РАН, 2004. С. 23-38.

5. Бородина М. А. Диалекты или региональные языки // Вопросы языкознания. 1982. № 5. C. 29-38.

6. Буряты / отв. ред. Л. Л. Абаева, Н. Л. Жуковская. М.: Наука, 633 с.

7. Герд А. С. Несколько замечаний касательно понятия «диалект» // Русский язык сегодня: сб. ст. М.: Азбуковник, 2001. Вып. 1. С. 45-52.

8. Герд А. С. Введение в этнолингвистику: курс лекций и хрестоматия. 2-е изд., исправл. СПб.: Изд-во С.-Петерб. ун-та, 2005. 457 с. 
9. Даль В. И. Толковый словарь русского языка. Современная версия. М.: ЭКСМОПресс, 2000. 736 с.

10. Егодурова В. М. Русский язык в Байкальском регионе: лексико-семантический аспект: монография. Улан-Удэ: Изд-во Бурят. гос. ун-та, 2018. 124 с.

11. Зварыкина И. С. Способы номинации регионализмов Астраханского края // Вестник Иркутского государственного лингвистического университета. 2014. № 2(27). C. 213-219.

12. Кадоло Т. А. Региональная лексика как проявление поликультурности // Язык и культура. 2011. № 2(14). С. 22-28.

13. Майоров А. П., Степанова И. Ж., Зырянова Е. В. Русская разговорная речь Бурятии: лингворегионоведческий аспект: монография. Улан-Удэ: Изд-во Бурят. гос. ун-та, 2018. $366 \mathrm{c}$

14. Оглезнева Е. А. Дальневосточный региолект русского языка: особенности формирования // Русский язык в научном освещении. 2008. № 2(16). С. 119-136.

15. Оглезнева Е. А. Дальневосточный региолект русского языка как региональный вариант русского национального языка // Слово: фольклорно-диалекто логический альманах. Материалы научных экспедиций. Благовещенск, 2013. Вып. 10. С. 27-37.

16. Оглезнева Е. А. К вопросу о границах дальневосточного региолекта // Вестник Бурятского государственного университета. 2014. Вып. 10. С. 65-68.

17. Словарь говоров старообрядцев (семейских) / под ред. Т. Б. Юмсуновой. Новосибирск: Изд-во СО РАН: Научно-издательский ОИГГМ, 1999. 539 с.

18. Ожегов С. И., Шведова Н. Ю. Толковый словарь русского языка. М.: А ТЕМП, 2010. $874 \mathrm{c}$

19. Трубинский В. И. Современные русские региолекты: приметы становления // Псковские говоры и их окружение: межвуз. сб. науч. тр. Псков, 1991. С.156-162.

20. Фасмер М. Этимологический словарь русского языка: в 4 т. Т. 3 (Муза - Сят) / пер. с нем. и доп. О. Н. Трубачева. 3-е изд., стер. СПб.: Терра - Азбука, 1996. 832 с.

21. Ушаков Д. Н. Толковый словарь русского языка: в 4 т. / под ред. Д. Н. Ушакова. M., 1935-1940. URL: http://www.ushakovdictionary.ru. (дата обращения: 18.03.2020).

\section{ON THE ORIGIN OF CERTAIN BORROWINGS IN THE REGIONAL LANGUAGE}

(a study of regionalism pimka/pinka)

Darima Sh. Kharanutova

Dr. Sci. (Phil.),

Dorzhi Banzarov Buryat State University

6 Ranzhurova St., Ulan-Ude 670000, Russia

dkharanutova@mail.ru

Anastasia I. Malatkina

Student,

Dorzhi Banzarov Buryat State University

6 Ranzhurova St., Ulan-Ude 670000, Russia

annastas2407@gmail.com

Abstract. The article deals with one of the problems of regional linguistics - the origin of regionalisms, it is considered on the example of the word pinka/pimka. We have revealed the concepts of regional dialect and regionalism, given different versions of the origin of the pinka/pimka regionalism, one of which is borrowing from English, and presented the results 
of a survey conducted during the study. Reconstruction of the etymological relations involves referring to explanatory and etymological dictionaries. The Etymological Dictionary of Borrowings, edited by A. E. Anikina made it possible to find answers to many questions. In the given dictionary entry, the etymology of the word under consideration is revealed in the aspect of the Proto-Slavic language as a source. We tend to believe that the chain ProtoSlavic dialects $\rightarrow$ Tungus-Manchu dialects $\rightarrow$ old-time dialects $\rightarrow$ regional language most accurately reflects the origin of the word pinka/pimka.

Keywords: regional dialect; regionalism; borrowings; etymological dictionaries; explanatory dictionaries; dictionary entry. 